\title{
PENGEMBANGAN PENILAIAN PORTOFOLIO UNTUK MENDUKUNG KEAKTIFAN SISWA PADA PEMBELAJARAN IPS DI SEKOLAH DASAR
}

\author{
Shafirra Bulanrizkia Efanda \\ Laila Fatmawati \\ PGSD FKIP Universitas Ahmad Dahlan \\ bulanefanda@gmail.com
}

\begin{abstract}
Learning will be memorable if students practice directly about the material being studied, but also the activity of students greatly affect their ability to absorb the material. With active students practice directly about the material being studied can help teachers in delivering the material being studied, especially on materials that are full of memorization as in the social studies in elementary school. For that new innovation is needed in the learning activities that are able to support students' activities in the learning process. This study aims to determine the steps of development of portfolio assessment and to determine the appropriateness of applying portfolio assessment to support student activeness in IPS learning. This research is a type of research development ( $R \& D)$. The procedure is to conduct preliminary study to know the potential and problems, data collection, product design, design validation, design revision, product test, product trial revision. Portfolio assessment instruments are validated by expert testers, ie evaluation experts, materials experts and learning specialists. This research was conducted at SD Muhammadiyah Kalangan in May 2017. The data collection instrument was done with expert validation, observation sheet, and student response sheet. In this research, data analysis is done with qualitative and quantitative. The results showed that in terms of quality portfolio assessment included in the category of very good, which is suitable to be used as application of learning. The results obtained from the validation of the expert evaluation obtained a value of 68.75 with good category, the results of the material experts obtained a value of 77.78 with good category, and the results of the expert learning obtained a value of 100 with very good category. The result of the test based on the students' appraisal was obtained by 90.27 with very good category, from the observer scores obtained the value of 81.25 with very good category..
\end{abstract}

Keywords: portfolio assessment, student activeness, $R \& D$.

\begin{abstract}
ABSTRAK
Pembelajaran akan berkesan apabila siswa praktek secara langsung mengenai materi yang dipelajari, selain itu juga keaktifan siswa sangat mempengaruhi kemampuannya dalam menyerap materi. Dengan siswa aktif praktek secara langsung mengenai materi yang dipelajari mampu membentuk guru dalam menyampaikan materi yang dipelajari, terutama pada materi-materi yang banyak berisi hafalan seperti pada pembelajaran IPS di SD. Untuk itu dibutuhkan inovasi baru dalam kegiatan pembelajaran yang mampu mendukung keaktifan siswa dalam proses pembelajaran.. Penelitian ini bertujuan untuk mengetahui
\end{abstract}


langkah-langkah pengembangan penilaian portofolio dan untuk mengetahui kelayakan penerapan penilaian portofolio untuk mendukung keaktifan siswa dalam pembelajaran IPS. Penelitian ini merupakan jenis penelitian pengembangan (R\&D). Prosedur yang dilakukan yaitu melakukan studi pendahuluan untuk mengetahui potensi dan masalah, pengumpulan data, desain produk, validasi desain, revisi desain, uji coba produk, revisi uji coba produk. Instrumen penilaian portofolio divalidasi oleh penguji ahli, yaitu ahli evaluasi, ahli materi dan ahli pembelajaran. Penelitian ini dilakukan di SD Muhammadiyah Kalangan pada bulan Mei 2017. Instrumen pengumpulan data dilakukan dengan validasi ahli, lembar pengamatan, dan lembar respon siswa. Dalam penelitian ini, analisis data yang dilakukan dengan kualitatif dan kuantitatif. Hasil penelitian menunjukan bahwa dari segi kualitas penilaian portofolio termasuk dalam kategori sangat baik, yang layak digunakan sebagai penerapan pembelajaran. Hasil tersebut diberoleh dari validasi ahli evaluasi diperoleh nilai 68,75 dengan kategori baik, hasil dari ahli materi diperoleh nilai 77,78 dengan kategori baik, dan hasil dari ahli pembelajaran diperoleh nilai 100 dengan kategori sangat baik. Hasil uji coba berdasarkan penilaian siswa diperoleh nilai 90,27 dengan kategori sangat baik, dari penilaian observer diperoleh nilai 81,25 dengan kategori sangat baik.

Kata kunci: penilaian portofolio, keaktifan siswa, $R \& D$.

\section{PENDAHULUAN}

Pendidikan merupakan proses yang terstruktur untuk mendapatkan informasi baru. Sistem pendidikan yang ada harus mengalami perubahan untuk meningkatkan mutu pendidikan Indonesia. Perubahan yang dimaksud berupa kurikulum pembelajaran yang ada serta inovasi pembelajaran yang dilakukan, dengan begitu proses pembelajaranya mampu berkembang dengan baik sesuai dengan perkembangan zaman. Kemajuan zaman yang sangat pesat saat ini menuntut guru lebih kreatif dalam melaksanakan proses pembelajaran. Salah satu tuntutan yang harus dilakukan untuk proses pembelajaran adalah melibatkan siswa secara aktif.

Pembelajaran yang melibatkan siswa secara aktif ini salah satu dengan mencoba menyelesaikan masalah saat proses pembelajaran berlangsung. Dengan melibatkan siswa untuk berperan aktif dalam proses pembelajaran siswa akan lebih mudah menyelesaikan masalah pembelajaran, agar mendapat pengalaman dan mampu memahami materi yang sedang di ajarkan. Menyelesaikan atau mencari tahu mengenai informasi baru yang didapat secara langsung akan mudah melekat diingatan siswa, dibandingkan dengan mendengarkan penjelasan dari orang lain.

Menurut riset dari National Training Laboratories di Bethel (Warsono \& Hariyanto, 2013) menunjukkan bahwa proses pembelajaran yang dilakukan guru dengan metode ceramah, memberikan tugas membaca, guru berpresentasi dengan audiovisual, dan dengan metode demontrasi mampu diterima siswa maksimal 30\% materi pembelajaran. Selanjutnya, jika pembelajaran dengan metode berdiskusi mampu diingat siswa maksimal $50 \%$. Kemudian jika siswa melakukan kegiatan, siswa mampu mengingat $75 \%$. Sedangkan yang mengharuskan siswa untuk praktek secara langsung mampu diingat siswa sebanyak 90\% materi pembelajaran. Dengan begitu pembelajaran dapat diperoleh melalui pengalaman, pengalaman tersebut didapat saat siswa memanfaatkan bahan ajar yang ada serta mampu memanfaatkan informasi yang diperoleh melalui bantuan orang lain.

Pembelajaran yang diperoleh dari suatu pengalaman inilah yang mampu meningkatkan kemampuan siswa. Tidak terkecuali pada pembelajaran IPS, dalam pembelajaran IPS siswa juga mendapatkan berbagai informasi baru dari apa yang mereka lakukan. Pembelajaran IPS ini merupakan adaptasi dari beberapa disiplin ilmu-ilmu social humaniora, serta kegiatan dasar manusia yang diorganisasikan disajikan secara ilmiah. 
Kosasih (Solihatin \& Raharjo, 2009) berpendapat idealnya dalam pembelajaran IPS adalah mendidik siswa dan memberi bekal kemampuan dasar kepada siswa untuk mengembangkan diri sesuai dengan minat, bakat, kemampuan, dan lingkungannya, serta memberikan bekal kepada siswa untuk melanjutkan ke jenjang yang lebih tinggi. Pola pembelajaran IPS menekankan pada unsur pendidikan dan pembekalan pada siswa. Penekanan pembelajaran ini bukan hanya sebatas pada upaya mencekoki siswa dengan konsep yang berupa hafalan.

Penjelasan mengenai pembelajaran IPS diatas maka dapat disimpulkan pembelajaran yang dilakukan juga tidak terlepas dari adanya penilaian terhadap segala aktivitas yang dilakukan siswa. Untuk mengetahui peningkatan atau kemampuan siswa dalam mempelajari pembelajaran IPS siswa diukur dari penilaian yang telah dilakukan. Proses penilaian yang dilakukan harus memperhatikan kumpulan hasil pekerjaan yang dilakukan siswa. Kumpulan pekerjaan siswa ini menunjukkan segala sesuatu yang diketahu siswa serta yang belum dipahami siswa. Penilaian yang menggunakan kumpulan hasil pekerjaan siswa ini berupa penilaian portofolio. Penilaian portofolio diartikan sebagai kumpulan fakta/bukti dan dokumen yang berupa tugas-tugas yang terorganisir secara sistematis dari seseorang secara individual dalam pembelajaran (Uno \& Koni, 2013).

Berdasarkan observasi yang dilakukan pada bulan Agustus 20016, peneliti menemukan permasalahan dalam pelakanaan proses pembelajaran, pada saat proses pembelajaran IPS berlangsung banyak siswa yang sibuk dengan kegiatannya sendiri tanpa memperhatikan penjelasan yang di sampaikan guru. Hal ini dapat dilihat, ketika ada beberapa materi yang siswa tidak dilibatkan secara langsung saat pembelajaran IPS berlangsung. Guru menjelaskan materi menggunakan metode ceramah, siswa hanya mendengarkan penjelasan yang disampaikan guru dan tidak secara langsung mencoba atau mencontohkan. Siswa menjadi sulit memahami materi yang diajarkan dan merasa bosan saat proses pembelajaran IPS berlansung. Di SD Muhammadiyah Kalangan pembelajaran yang dilakukan belum menerapkan penilaian portofolio dalam pembelajatan IPS. Portofolio digunakan sebagai bahan evaluasi pembelajaran yang sudah berlangsung sebelumnya. Portofolio akan memudahkan guru dan siswa melakukan evaluasi mengenai apa yang telah dipelajari dan sejauh mana kemampuan yang sudah dimiliki siswa.

Masih banyak guru yang belum memahami penilaian portofolio. Penerapan penilaian portofolio dalam bidang pendidikan masih merupakan fenomena baru. Penggunaan penilaian portofolio untuk penilaian hasil belajar siswa mulai ramai dibicarakan bersamaan dengan dilaksanakan kurikulum berbasis kompetensi (KBK). Oleh karena itu, wajar jika pemahaman guru dan praktisi pendidikan lainnya terhadap portofolio masih kurang. Portofolio pada dasarnya menilai hasil karya-karya siswa secara individu pada satu periode untuk suatu mata pelajaran. Akhirnya satu periode hasil karya tersebut dikumpulkan dan dinilai oleh guru dan peserta didik sendiri. Dari informasi tersebut guru dan siswa dapat menilai sejauh mana perkembangan kemampuan siswa tersebut melakukan perbaikkan (Suwandi, 2010).

Penilaian portofolio yang memanfaatkan hasil karya siswa sebagai bahan untuk menilai sejauh mana ketercapaian yang sudah dimiliki siswa dalam memahami materi yang dipelajari. Penerapan penilaian portofolio ini mampu mendukung siswa untuk aktif dalam proses pembelajaran yang dilakukan. Pembelajaran yang memumbuhkan keaktifan siswa ini mampu memotivasi siswa lebih bersemangat lagi mempelajari materi selanjutnya. Siswa akan terus berusaha untuk menampilakan karya yang terbaik dalam setiap pembelajaran yang dilakukan. Menurut Masnur Muslich (2011) karakteristik penilaian portofolio merupakan komperhensif, terencana dan sistematis, terpola dan autentik. Sesuai dengan karakteristik yang diungkapkan tersebut dalam penilaian portofolio didapat 
informasi siswa secara menyeluruh tentang kompetensi siswa dalam tugas-tugas dalam suatu mata pelajaran.

Proses pembelajaran yang sudah dilaksanakan masih belum sesuai dengan tujuan pembelajaran yang sudah diungkapkan para ahli, belum sesuai tersebut membuat kurang berhasilnya proses pembelajaran yang diharapkan. Berdasarkan analisis yang dilakukan, maka diperlukan solusi yang mampu meningkatkan keaktifan dalam proses pembelajaran IPS. Salah satu solusinya yaitu mengembangkan penilaian portofolio. Penilaian portofolio ini diharapkan mampu meningkatkan keaktifan siswa dalam proses pembelajaran, dengan begitu pemanfaatan penilaian portofolio ini mampu untuk menumbuhkan atau meningkatkan keaktifan siswa.

Hasil penelitian membuktikan bahwa penggunaan portofolio mampu mendukung keaktifan siswa dalam proses pembelajaran pendapat Saraswati,dkk (2016), secara teoritis dapat dikatakan bahwa penggunaan penialain portofolio dapat meningkatkan keaktifan siswa. Pembelajaran yang dilakukan ini memberikan siswa keberhasilan dalam proses pembelajaran terjadi peningkatan keaktifan belajar dengan pendekatan saitifik berbasis asesmen portofolio pada siswa kelas V SD. Disamping itu juga terjadi peningkatan kompetensi pengetahuan yang dimiliki siswa.

Sesuai dengan analisis kebutuhan tersebut maka, dalam proses pembelajaran IPS dikembangkan penilaian portofolio. Siswa akan lebih mudah memperbaiki kesalahan dan mempertanggung jawabkan hasil karyanya dengan penerapan penilaian portofolio pada pembelajaran IPS. SD Muhammadiya Kalangan belum mengembangkan penilaian portofolio untuk mendukung keaktifan siswa dalam proses pembelajaran IPS.

Berdasarkan pada pemaparan sebelumnya, terdapat dasar permasalahan yaitu, pembelajaran yang dilakukan kurang melibatkan siswa secara langsung, guru lebih berperan aktif dalam proses pembelajaran dibandingan siswa, proses pembelajaran yang dilakukan belum ada pemanfaatan portofolio dalam proses pembelajaran, pembelajaran IPS belum menerapkan penilaian portofolio untuk menilai hasil karya siswa.

\section{METODE PENELITIAN}

Penelitian ini menggunakan penelitian pengembangan atau yang lebih dikenal dengan Research and Development (R\&D) Sugiyono (2015: 297). Penelitian dan pengembangan ini merupakan suatu proses atau langkah-langkah untuk mengembangakan suatu produk baru atau menyempurnakan produk yang telah ada, yang dapat dipertanggung jawabkan. Penelitian dan pengembangan atau dalam bahas inggris "Research and Development" adalah metode penelitian yang digunakan untuk menghasilkan produk tertentu, dan menguji keefektifan produk tersebut. Langkah pengembangan menurut Borg and Gall (Sugiyono, 2015:490). Sesuai bagan langkah-langkah penggunaan model R \& D maka dalam penelitian pengembangan penilaian portofolio hanya menggunakan hingga langkah ke tujuh, dikarenakan keterbatasan waktu, tenaga, dan biaya. Waktu penelitian dilakukan pada bulan Mei 2017. Jenis data yang digunakan dalam penelitian pengembangan penilaian portofolio adalah data kuantitatif dan data kualitatif. Data kualitatif mengenai penilaian portofolio berupa masukan, tanggapan, komentar, dan saran dari validasi ahli, dan guru yang digunakan untu merevisi produk yang dikembangkan. Data kuantitatif pengembangan penilaian portofolio adalah dari hasil uji kelayakan produk yang diperoleh dari jumlah penilaian dosen ahli, observer dan siswa yang berupa skor dan dikategorikan menjadi kategori tertentu.

Instrumen pengumpulan data yang digunakan dalam penelitian ini yaitu lembar pengamatan untuk dosen ahli yang terdiri dari lembar validasi instrumen penelitian, lembar validasi oleh ahli materi dan ahli pembelajaran, observer dan siswa. Lembar validasi Ahli 
yang dikembangkan oleh peneliti Manfaat dari lembar validasi yang ada untuk mendapatkan data mengenai kevalidan serta mengetau kelayakan suatu produk yang dikembangkan. Lembar validasi pada penelitian ini disusun dan dikembangkan dengan 4 alternatif jawaban yaitu $\mathrm{TB}(1), \mathrm{KB}(2), \mathrm{B}(3)$, dan $\mathrm{SB}(4)$.

Tabel 1.Skala Penilaian

\begin{tabular}{|c|c|c|}
\hline Jawaban yang dipilih & Bobot & Kategori \\
\hline Pilihan pertama & 4 & Sangat Baik \\
\hline Pilihan kedua & 3 & Baik \\
\hline Pilihan ketiga & 2 & Kurang Baik \\
\hline Pilihan keempat & 1 & Tidak Baik \\
\hline
\end{tabular}

Skala penilaian pada penelitian ini secara lebih rinci adalah sebagai berikut: (1) Kategori sangat baik (SB) meliputi: sangat mudah dipahami, sangat menarik, sangat jelas, sangat sesuai, sangat menarik, sangat bermanfaat diberi nilai 4. (2) Kategori baik (B) meliputi: mudah dipahami, menarik jelas, sesuai, menarik, bermanfaat, diberi nilai 3 . (3)Kategori kurang baik (KB) meliputi: kurang mudah dipahami, kurang menarik, kurang jelas, kurang sesuai, kurang menarik, kurang bermanfaat diberi nilai 2. (4) Kategori tidak baik (TB) meliputi: tidak mudah dipahami, tidak menarik, tidak jelas, tidak sesuai, tidak menarik, tidak bermanfaat diberi nilai 1 .

Semua data yang dikumpul kemudian dimasukan kedalam rumus, rumus yang diperoleh merujuk pada Purwanto M.N (2013:112) sebagai berikut

$$
S=\frac{R}{\mathrm{~N}} \times 100
$$

Lembar pengamatan observer dan respon siswa digunakan dalam penelitian ini disusun dan dikembangkan ole peneliti. Manfaat dari lembar pengamatan observer dan siswa ini adalah untuk mendapatkan data tentang tanggapan observer dan siswa mengenai pembelajaran yang dilakukan dengan penilaian portofolio. Lembar pengamatan disusun dengan penilaian yang sama dengan lembar validasi ahli. Setelah semua dihitung menggunakan penilaian sesuai rumus yang ada maka diperoleh nilai yang kemudian dikonversikan berdasarkan pendapat Suharsimi (2013: 281), sebagai berikut :

Tabel 2. Penilaian observer dan respon siswa

\begin{tabular}{ll} 
Nilai & Kategori \\
\hline $80-100$ & Sangat Baik \\
\hline $66-79$ & Baik \\
\hline $56-65$ & Kurang Baik \\
\hline $130-49$ & Tidak Baik
\end{tabular}

\section{HASIL PENELITIAN}

Hasil penilaian portofolio oleh dosen ahli, observer dan siswa pada uji coba produk (kelompok kecil) adalah sebagai berikut.

1. Analisis Data Kualitatif

a. Analisis Ahli Evaluasi

Validasi ahli media dilakukan oleh Dr. Suyatno, M.Pd.I yang merupakan salah satu dosen Pendidikan Guru Sekolah Dasar (PGSD) yang berkompeten dalam bidang ilmu pendidikan dengan latar belakang pendidikan S2. Validasi instrumen penilaian portofolio ole ahli evaluasi pada tanggal 26 April 2017. Hasil validasi oleh ahli evaluasi adalah 68,75. Berdsarkan kategori, instrumen portofolio yang dikembangkan mendapatkan penilaian "Baik". Selain memberikan penilaian berupa skor, ahli media juga memberikan penilaian berupa komentar dan saran yang 
bersifat membangun agar produk yang dikembangkan dapat lebih baik lagi. Saran yang diberikan ahli evaluasi adalah sebagai berikut :

1) Perlu diperbaiki penulisan yang masih kurang tepat sesuai pada draf

2) Teknik penilaian diperbaiki sesuai dengan kaidah Bahasa Indonesia

3) Tampilan dibuat lebih menarik untuk anak SD

b. Analisis Ahli Materi

Validasi ahli materi dilakukan oleh ibu Vera Yulia Erviana, M.Pd yang merupakan salah satu dosen Pendidikan Guru Sekolah Dasar (PGSD) yang berkompeten dalam bidang materi dan kurikulum SD dengan latar belakang pendidikan S2. Validasi instrumen penilaian portofolio oleh ahli materi pada tanggal 3 Mei 2017. Hasil validasi oleh ahli materi adalah 77,78. Berdsarkan kategori intrumen penilaian portofolio mendapatkan penilaian "Baik". Ahli materi memberikan saran kepada peneliti yang bertujuan agar produk penilaian portofolio dapat menjadi lebih baik lagi. Saran yang diberikan oleh ahli materi adalah :Indikator disesuaikan lagi dengan KD dan Soal

1) Rubrik pada penilaian kliping diperbaiki

2) Kesalahan penulisan atau typo diperbaiki

3) Dibuat lebih menarik lagi

c. Analisis Ahli Pembelajaran

Validasi ahli pembelajaran dilakukan oleh ibu Laila Fatmawati, M.Pd yang merupakan salah satu dosen Pendidikan Guru Sekolah Dasar (PGSD) yang berkompeten dalam bidang kependidikan dengan latar belakang pendidikan S2. Validasi instrumen penilaian portofolio oleh ahli pembelajaran pada tanggal 21 April 2017. Hasil validasi ahli pembelajaran adalah 100. Berdsarkan kategori, instrumen penilaian portofolio mendapatkan penilaian "Sangat Baik". Seperti halnya ahli evaluasi, ahli materi dan ahli pembelajaran juga memberikan komentar dan saran guna memperbaiki produk agar lebih baik. Saran dari ahli pembelajaran adalah:

1) Tujuan pembelajaran dalam kegiatan pembelajaran harus sesuai $A B C D$

2) Skor dalam rubrik harus seimbang

d. Analisis Uji Coba Produk

Uji coba produk dilakukan di SD Muhammadiyah Kalangan dengan jumlah 12 siswa, nilai yang diperoleh dari tanggapan siswa mengenai pembelajaran yang dilakukan sebesar 90,27 termasuk dalam kategori sangat baik. Sedangkan penilaian observer terhadap pelaksanaan proses pembelajaran yang dilakukan sebesar 81,28 termasuk dalam kategori sangat baik.

2. Analisis Data Kuantitatif

Analissi data kuantitatif digunakan untuk mengelola data yang diperoleh dari hasil pengiwsian validasi ahli evaluasi, ahli materi, ahli pembelajaran. Kemudian data yang diperoleh disajikan dalam diagram batang. Hasil data kuantitatif instrumen penilaian portofolio dari penilaian ahli evaluasi, ahli materi, ahli pembelajaran, dijelaskan pada tabel berikut:

Tabel 3. Tabel Data Kuantitatif

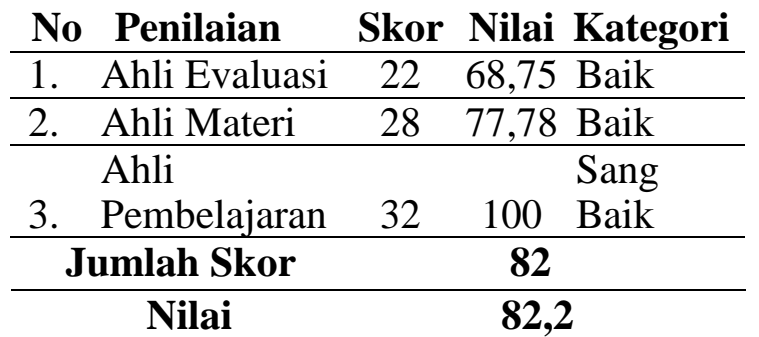




\section{Kategori Sangat Baik}

Tabel tersebut menunjukkan hasil penilaian terhadap penilaian portofolio dengan jumlah skor yang diperoleh 82 sehingga mendapat nilai dengan kategori "Baik Sekali". Berikut disajikan diagram penilaian oleh dosen ahli dan uji coba produk.

Gambar1. Diagram Hasil Penilaian Kualitas Instrumen Penilaian Portofolio

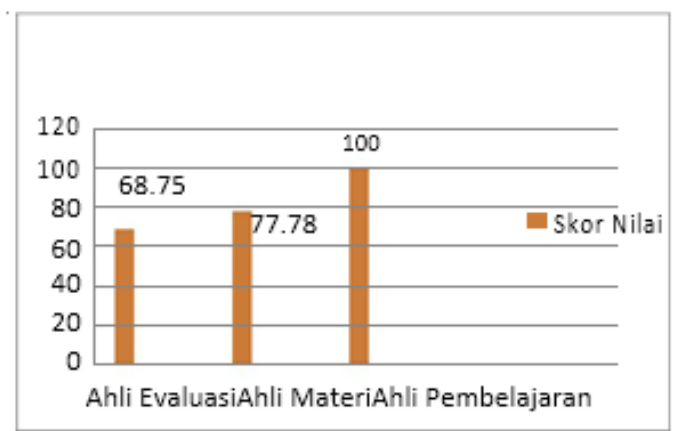

Data yang diperoleh berdasarkan uji coba produk sesuai penilaian dari observer serta respon siswa. Kemudian data yang diperoleh disajikan dalam diagram batang. Hasil data kuantitatif penilaian portofolio untuk mendukung keaktifan siswa dari penilaian observer dan respon siswa disajikan dalam tabel sebagai berikut :

Tabel 3. Pengamatan

\begin{tabular}{|c|c|c|c|c|}
\hline No & Penilaian & Skor & Nilai & Kategor \\
\hline \multirow[b]{2}{*}{1.} & & & & Sangat \\
\hline & Observer & 91 & 81.25 & Baik \\
\hline & Respon & & & Sangat \\
\hline & Siswa & 260 & 90,27 & Baik \\
\hline \multicolumn{2}{|c|}{ Jumlah Skor } & \multicolumn{3}{|c|}{351} \\
\hline \multicolumn{2}{|c|}{ Nilai } & \multicolumn{3}{|c|}{85,76} \\
\hline \multicolumn{2}{|r|}{ Kategori } & \multicolumn{3}{|c|}{ Baik Sekali } \\
\hline
\end{tabular}

Tabel tersebut menunjukkan hasil penilaian terhadap penilaian portofolio dengan jumlah skor yang diperoleh 351 sehingga mendapat nilai dengan kategori "Baik Sekali". Berikut disajikan diagram penilaian

Gambar 2. Diagram Hasil Penilaian Kualitas Instrumen Penilaian Portofolio Uji Coba Produk

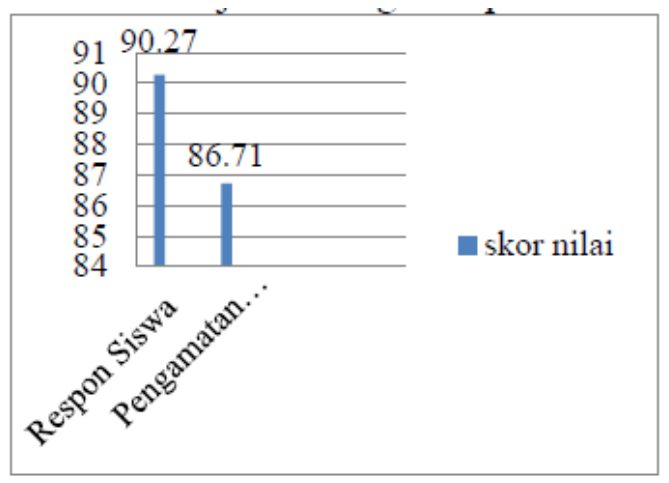

\section{KESIMPULAN}


Berdasarkan hasil penelitian dan pengembangan penilaian portofolio untuk mendukung keaktifan siswa pada pembelajaran IPS di SD maka dapat diambil kesimpulan sebagai berikut, langkah- langkah pengembangan penilaian portofolio untuk mendukung keaktifan siswa pada pembelajaran IPS di Sekolah Dasar. Langkah dalam penelitian ini dimulai dengan menganalisis permasalahan yang ada di Sekolah Dasar Muhammadiyah Kalangan. Setelah di dapat suatu permasalahan langkah selanjutnya mengumpulkan data mengenai permasalahan yang ada. Setelah itu dilanjutkan dengan proses desain produk, dalam hal ini adalah instrumen portofolio yang kemudian divalidasikan kepada para ahli. Tujuannnya untuk mengetahui kelayakan untuk di terapkan di Sekolah Dasar.

Berdasarkan data validasi ahli yang diperoleh menunjukkan hasil bahwa instrumen portofolio dari segi kualitas termasuk ke dalam kategori sangat baik. Hasil data tersebut adalah sebagai berikut: untuk ahli evaluasi mendapat nilai 68,75 , untuk validasi ahli materi mendapat nilai 77,78, serta validasi ahli pembelajaran mendapat skor 100. Sesuai dengan penilaian yang diperoleh tersebut dapat disimpulkan bahwa kelayakan penilaian portofolio termasuk kedalam kategori sangat baik, sehingga hasil penelitian yang dilakukan di SD Muhammadiyah Kalangan untuk mengetahui kelayakan instrumen pada pembelajaran didapat nilai sebagai berikut: untuk hasil pengamatan observer mendapat nilai 89,71 dan dari respon siswa melalui kegiatan yang dilakukan mendapat nilai 92,27. Dari data tersebut dapat disimpulkan bahwa penerapan penilaian portofolio untuk mendukung keaktifan siswa dari segi kelayakan dikategorikan sangat baik.

\section{DAFTAR PUSTAKA}

Mansur Muslich. 2011. Penilaian Berbasis Kelas dan Kompetensi. Bandung: PT Refika Aditama.

Purwanto, M. N. 2013. Prinsip-prinsip dan Teknik Evaluasi Pengajaran. Bandung: PT Remaja Rosdakarya

Saraswati, I.A.D., Wiasa, K.N., \& Suara Made. 2016. Penerapan Pendekatan Saintifik Berbasis Asesmen Portofolio Untuk Meningkatkan Keaktifan Dan Penguasaan Kompetensi Penetahunan IPATema Sejarah Peradapan Indonesia Siswa Kelas V SD Negeri 14 Pedungan. http://ejournal.undiksha.ac.id/index.php/JJPGSD/article/viewFile/7150/4878. Diakses 27 September 2016 (21.23) (Vol 4(1). 2016)

Solihatin, E., \& Raharjo. 2009. Cooperatif Learning Analisis Model Pembelajaran IPS Jakarta: PT Bumi Aksara.

Sugiyono. 2015. Metode Penelitian Pendidikan Pendekatan Kuantitatif, Kualitatif, da $R \& D$. Bandung: Alfabeta.

Suharsimi,A .2012. Prosedur Penelitian. Jakarta : Rineka Cipta

Suwandi, S. 2010. Model Asesmen Dalam Pembelajaran. Surakarta: Yuma Pustaka bekerja sama dengan FKIP UNS.

Uno, H. B., \& Koni, S. 2013. Assesmen Pembelajaran. Jakarta: PT Bumi Aksara. 
Warsono, \& Hariyanto. 2013. Pembelajaran Aktif. Bandung: PT Remaja Rosdakarya.

Yus, A. 2006. Penilaian Portofolio Untuk Sekolah Dasar. Jakarta: Departemen Pendidikan Nasional. 